\begin{tabular}{cc}
\hline \hline 寄 \\
\hline \hline
\end{tabular}

変形物体間の接触の力学に関する IUTAM シンポジウム出席報告*

$$
\text { 川建 和 雄** }
$$

国際理論応用力学連合 IUTAM は, 国際学術連合 会議 ICSU の後援の下に, 毎年力学の特定の問題に 関する国際シンポジウムの幾つかを，そしてさらに4 年に 1 回国際会議を組織している. 1972 年 8 月ソビエ 卜連邦モスクワ市で行われた第 13 回国際理諭応用力 学会議総会において，表記シンポジゥムの開催が決定 され，そのために科学委員会が任命された. 同委員会 の構成は, N. H. ARUTJUNJAN (ソ連), H. BUfLER (西ドイッ)，L.E. Goodman (アメリカ), A.Ju. IŠLINSKIJ (ソ連)，K. L. JOHNSON (連合王国)，W. NoWACKI (ポーランド), A.D. de PATER (委員長, オランダ)，D. TABOR（連合王国）の8名である.シ ンポジウムは 1974 年 8 月 20 日から 23 日まで 4 日間, オランダ・エンスヘーデ (Enschede) 市で開かれた. 同市は首都アムステルダムから東へ約 $130 \mathrm{~km}$, 鉄路 2 時間あるいは空路 30 分の地点にある.オランダ第 3 番目の工科大学として, 広い敷地の中に，1964年 9 月開かれたという，新興のトウエンテ (Twente) 工科 大学の数学科の 1 室が, 会場にあてられた. 前もって 配布された資料によれば, 参加者数 76 , 発表論文数 27 であった，その後 2 件が取り下げられ，1件が加わ ったので，結局 26 件の発表が行われた. 国別内訳は， 連合王国およびアメリカ各 8 ，オランダおよびソ連各 2, デンマーク, フランス, 西トイッ, カナダ, イン ドおよび日本各 1 である. 発表には 35 分が割り当て られ，さらに討論に 10 分が準備された. 議事録は, A. D. de PATER および J.J. KALKER が編者となり, Delft 工科大学出版会より, 本年春仙は刊行さ机る予 定である.

初日, Twente 工科大学長 P. J. ZANDBERGEN 教授 の歓迎の辞, IUTAM 事務局メンバー W. T. KoITER 教授の挨拶，科学委員会の長 A.D.de PATER 教授に よるシンポジゥムの紹介，さらに同教授による 16 ミ リ映画 Hunting Morement in Railway Vehicle の映写があり引引き続き論文発表（座長 L. E. GooDMAN) に入った. J. J. KALKER (Delft Univ. Tech.) は, 1959 年フランスの SIGNORINI により創始され

*昭和 50 年 1 月 31 日原稿受理 IUTAM Symposium on the Mechanics of the Contact between Deformable Bodies, held at Enschede, 20-23 August. 1974.

***州大学灾用力学研究所: Kazuo KawATATE
た，仮想仕事が負になることを出発点とする，接触問 題の変分原理を紹介した後, 接触に関する数理解析を 詳く分類，現在まで解かれた問題と，今もって着手 されていない問題を，区別して示した．K. L. JoHNSON (Camb. Univ.) 估, 異質 2 物体の接触面上の摩擦力, 滑面の相互接触に睍れる分子間力に基つく凝着，ラン ダム表面粗度をむつ物体の弾性球との接触等, 主とし て彼の手による理論的・実験的研究を通じて，如何に HERTZ の理論が拡張されてきたかを回顧した. 午後

(座長 G. M. L. Gladwell), J.B. Alblas (Eindhoven Univ. Tech.) は, 剛円柱をはさむ 2 枚の弾性板 飞関する 2 次元弾性接触問題の解析解を与えた. Th. G. JoHNS (Batelle Columbus Lab.) は, 任意形状の 多重層等方弾性体の垂直接触に就いて, 接触面皘 - 変 位・接触応力を求兴数值計算法を述へた. L. E. Goodman (Univ. Minn.) は, 任意厚の弾性層被膜を 持つ, 元来球状の 2 箇の剛体が，その中心を結ぶ線上 に压し付けられ，かつ接触面上に滑りを生ずるように 接線荷重が作用するときの，表層中の応力之変形汇就 いて, 近似解析解を与えた. ての夕, town hall にお いて，市長のレセプションが行われた.

第 2 日午前 (座長 G. HerRmanN, Stanford Univ.), B. L. Abramjan (Acad. Sci. Armenian SSR) 弾性半空間の表面に沿って薄い剛円柱およびパンチが 移動する問題を考察した. Hankel 積分で表した Papkovich-Neuber 型調和函数によって解き，用いた末 知の皘分函数は Bessel 函数を含む双皘分方程式系の 解を求めることから決定する。これに対し，GLADWELL および SPENCE が，既に解かれた問題であると，クレ 一ムを付けた. 発表者は手法が新しいと突き離した. 英連邦対ソ連邦のての間の応酬住激烈であった.D.A. SPENCE (Univ. Oxford) は, 弾性半空間伈2 次元あ るいは軸対称パンチを压し付ける問題を取り上げた. 適当な定数を選ぶと, 弾性一弾性接触が形式的に用一 弾性接触問題に変換されるとと，およびべキ型形状 $z \propto r^{n}$ の物体による圧入問題では，その接触応力が平 頭パンチによる壬入時の接触応力の皘分で与えられる こと，港ついて相似則を提唱した．J. DUNDURS (Northwestern Univ.) は, 変形状態での接触の拡少 り $C$ を初期接触 $C_{0}$ と比較するととによって，物体 
間の接触を, 後退型 $C \subset C_{0}$ および前進型 $C \nsubseteq C_{0} に$ 分類し, 線型弾性体の後退型接触では, 応力は荷重に 比例し，接触の拡がりは荷重に独立であることを指摘 した. J. Christoffersen (Tech. Univ. Denmark) は，弾塑性基礎上を定速で動く剛ローラによって生ず る塑性変形問題を取り扱った. 表面のゆがみ, 剛口ー ラの駆動力, およびそのなす仕事と塑性仕事の平衡等 を諭じた. M. BOUCHER (Univ. Paris) は, 粘弾性体 における SIGNORINI の問題を取り上げ，図数空間論 に基づき，一意性・存在定理を証明した. 午後（座長 L. Solomon, Univ. Poitier), F. F. Ling (Rensselaer Polytechnic Inst.) は，半空間の熱弾性応答汇関する基 本解を求め，てれを用いて転がり接触中の熱の影響を 解析した, J. R. BARBER(Univ. Newcastle-upon-Tyne) は，調和ポテンシャル函数 2 箇により表わされる熱弾 性平衡方程式の解を，剛・摩擦無し・熱パンチによる 半空間の圧入問題汇適用，特に，非軸対称熱境界条件 下の棈円パンチおよび円柱パンチに就いて考察した. R. A. BURTON(Northwestern Univ.) は, 最初に, 摩 擦熱江伴う变形の結果，一梯汇接触した平面が，たが いに分離した領域によって用まれる, 接触班点 (patch) に移行する様子を, 16 ミリ・フィルムの映写をして示 した. 次に，熱伝導率の差加物体の熱弾性的相互作用 に大きく影響するととに着目しつつ，熱良導体上を熱 絶縁体が滑へる場合汇就いて解析し，軸対称接触班点 を論じた．との結果は，乾燥接触あるいは境界潤滑の 存在する, シールあるいはブレーキに適用されるとい j. H. KRAUSE (Aachen Univ. Tech.) は, 2 箇の たがいに別別に駆動される円柱状鋼製ディスクを用い て転がり摩擦実験を行い，表面層・表面粗度・硬度分 布・結晶寸法・格子歪・結晶配向等の摩擦係数に及ほ す影響を報告した。

第 3 日午前(座長，D. TABOR, Cambr. Univ.), J. F.
ARCHARD (Univ. Leicester) はっランダムな構造を 有する表面の計算機シミュレーションに就いて述へ， 2 籄の接触表面の触針計記録加ら得られる比較的小規 模の標本を用いる解析法を示した．F.T. BARWELL (Univ. Coll. Swansea) は，固体表面の微視組織を記 述するに当たり，TSUKIZOE および HISAKADO によ り提案された模型を用い，触針測定による記録を解析 - 整理した. 光学的な測定により求めた接蜰点寸法の 確率分布曲線を, この強針法による予測と比較, 接触 寸法 $11 \mu \mathrm{m}$ 以上の笧囲での，一致は良好なることを報 告した。 また，摩耗および潣滑における表面組織の果 たす役割に就いて, 調査しかつ考察を加えた.J. HALLING (Univ.Salfold) は, 粗面を球状凹凸の array で あると仮定して解析を行い，簡単な実験によって得ら れる加工硬化定数を訫算に導入，粗面接触に及活す加 工硬化の影響を例示した. A. SCHALLAMACH (Natural Rubber Producer's Res. Assoc., UK) は, 摩摖力の 荷重・温度・速度および接触面の目視観測から，滑軌 上のゴム摩擦は分子凝着に基つくくのであり，かつ比 較的柔らかいゴムでは，滑り方向之直角な狭い帯域内 で軌道と接触を失うような waves of detachment を 伴う滑りが生ずること，さらに，粗軌上ではその凹凸 がゴムを変形させ機械的エネルギー損失の起こること 等を示した. 午後は excursion, 国立公園 De Hoge Velume にある，ゴッホの作品を数多く蔵めている， Kıöller-Müller 美術館を訪れた。

最終日午前 (座長 A. Ju. IŠLINSKIJ)， G. M. L. GLADWELl (Univ. Waterloo, Canada) は，軸対称分 布荷重を及ぽす半径有限の板乞弾性半空間の接触を考 察した. 問題は，固有値型の Fredholm 積分方程式 を解くととに帰せられた. P.R. NAYAK (Tata Engng. \& Locomotive CO., India) は, 弾性固体がたがいに 転がりあるいは滑る時に生ずる接㑁振動を論じた．こ

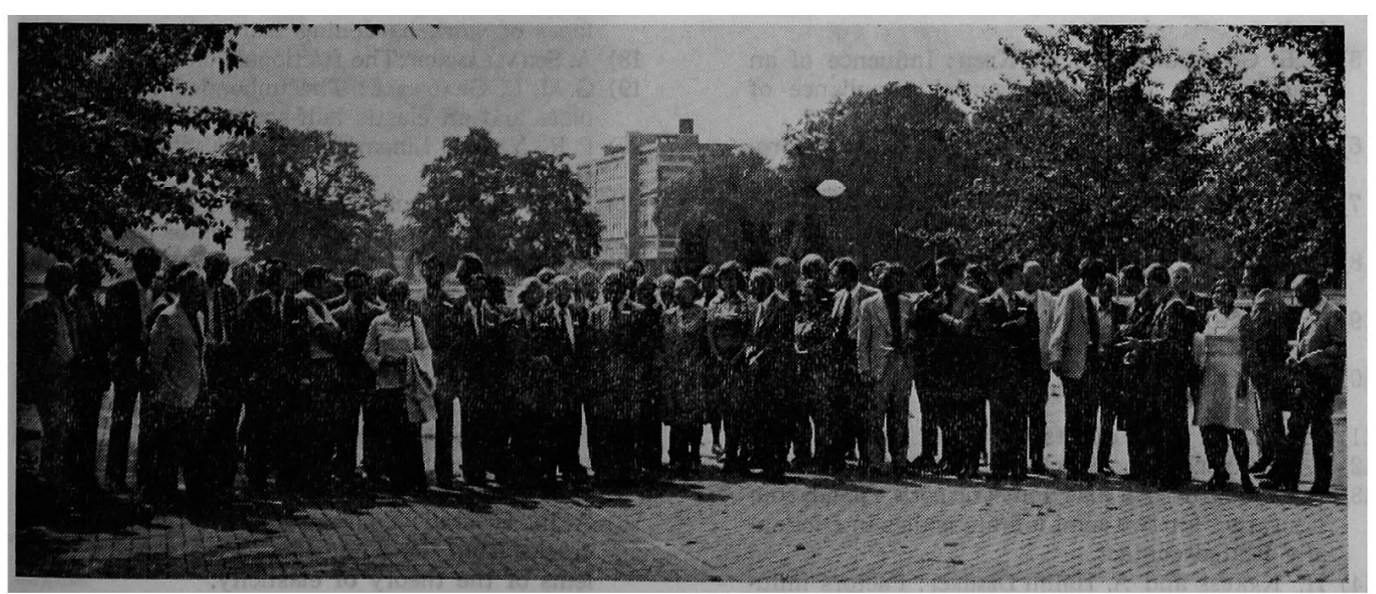

第 1 図 美術館へ向けて劸揃い。Twente 工科大学. 1974 年 8 月 22 日 
の振動の重要な動的要秦は非線型バネである．計算が 煩雑なので，一般的に線型近似をし，乙れを例えばボ ール・ベアリングに適用，さらに計算精度の評価を行 った. Y.M. TSAI (Iowa State Univ.) は, 軸対称投 射体と有限厚弾性板の動的接触応力を，積分変換法を 用いて運動方程式を解くことにより求め，応力が静的 な場合の解と波動の影響を表す積分の和で与えられる ことを示した. P.A. ENGEL (IBM, New York) は, 繰り返し衝乫を受ける面上の接触応力を，準静的な計 算を用いて求めた，さらに，表面破損の判定式および 接触面形状の変化に就いて述べた. KAWATATEは, 平頭剛体之半無限粘弾性体の䡓突による, 接触力の時 間的変動を中心に，応力・変位の計算法わよびその検 証に就いて発表した. 運動方程式から重波動方程式を 導き数值逆 Laplace 変換を用いる方法と, ウレタン ・ゴム板を供試片とするモアレ縞法の実験である．午 後 (座長 A. D. de Pater, Delft Univ. Tech.), L. A. Mitchel (Central Electricity Generating Board, UK) は，核反応师の多くの部品の性能が凝着・摩擦 および摩耗によって決定される現状を述へ，完全では ないけれどす，接触理論がこれまでに果たしてきた役 割を評価するととすに，今後の発展の方向に就いて若 干の示唆をした．特に，実用上重要な摩耗 (wear) の 問題は，現接触理諭の最弱点であると強調した． B. PAUL (Univ. Pa.) は, 多重連結領域における接触応 力の数值計算法を提示した. これを中央部に腐食 pit のある 2 球の接触に適用, pit 直径の応力集中に及ぽ
す影響を例示した. A. Ju. IŠLINSKIJ (USSR Acad. Sci.) は, 弾性接触論と crack 理論との対比を行っ た. 一般討論では，H. PARLAND (Finland) が, sleeve joint の滑り等に就いての研究の有無を問い, KALKER と MITCHELL が若干の文献を挙げた. 分類に関連し て，HERRMAN は，弾性安定問題での接触の分野を指 適した. 加うるに, BARBER, T.H.C. CHILDS (UK), M. Frémond (France). I. PÁczelt (Hungary), J. R. WILLIS(UK) が，各々，短かい論文を読んだ.との夕， キャンパスで, final banquet が盛大に催された.

このように，固体接触に関する基礎加ら応用に到る 広䇢多岐にわたる分野の論文が発表された。熱弾性, 表面粗度，動的問題，あるいは摩耗の分野には，未だ 数多くの問題が残されているようである.今後の発展 に期待しなりればならない.

参加者の大部分は，静かなキャンパス内の一隅にあ る学生寮を利用した．滞在期間中快晴に惠まれ，美し い風景を満喫するととができた．費用は，登録 50 . 晚 餐会 25 ・宿泊含朝食（5）75・屋食および夕食（各 4) 75 ・ 小旅行参加 25 , 締めて 250 オランダ・ギル ダ，邦貨に換算して約 2 万 7 千円であった。

なお,シンポジゥム出席に当たり, 文部省昭和 49 年 度国際研究集会派遣旅費が支給された。また，多くの 方方，会長および西部支部長を初めとする航空宇宙 学会関係各位，並びに，所長を初めとする応用劢学研 究所関係各位加ら，愁篤なる配慮・激励・忠告を戴い た.ととに記して，樑く感謝の意を表す.

\section{第1表 発表論文一覧}

1) J.J. KaLKER: Aspects of contact mechanics.

2) K. L. Johnson: Non-Hertzian contact of elastic spheres.

3) J. B. Alblas: On the two-dimensional contact problem of a rigid cylinder, pressed between two elastic layers.

4) Th. G. Johns and A.W. Leissa: The normal contact of arbitrarily shaped multilayered elastic bodies.

5) L.E. Goodman and L.M. Keen: Influence of an elastic layer on the tangential compliance of bodies in contact.

6) B.L.Abramjan: Some asymmetrical contact problems for semispace.

7) D.A. SPENCE : Similarity considerations for contact between dissimilar elastic bodies.

8) J. Dundurs: Properties of elastic bodies in contact.

9) J. Christoffresen: Small scale plastic flow associated with rolling.

10) M. BOUCHER : Signorini's problem in viscoelasticity.

11) F.F. LiNG : Heat effects in rolling contact.

12) J.R. BARBer: Thermoelastic contact problems.

13) R. A. Burton : An axisymmetric cotact patch configuration for two semi-infinite bodies in frictionally heated contact.

14) H. Krause and A. Halim Demircs: Factors influencing the real trend of the coefficient of fric- tion of two elastic bodies rolling over each other in the presence of dry friction.

15) J. F. Archard, R. T. Hunt and R. A. Onjon: Stylus profilometry and the analysis of the contact of rough surfaces.

16) F. T.Barwell, M. H. Jones and S. D. Probert : The interaction and lubrication of rough surfaces.

17) J. HaluING and K. A. NuRI: Contact of rough surfaces of work hardening materials.

18) A. Schallamach :The frictional contact of rubber.

19) G.M. L. GRADweLL: The unbonded contact of a plate and an elastic half-space.

20) P. R. NAYAK : Linearized contact vibration analysis.

21) Y.M. Tsar: Dynamic contact stresses produced by impact in elastic plates of finite thickness.

22) P.A. ENGEL :Impact on a worn surface.

23) K. Kawatate: Transition of collision contact force between a viscoelastic space and a flatheaded rigid body.

24) L.A.Mrtchell: Applications for contact theories in nuclear reactor technology.

25) K. P. Singh, B. Paul and W.S. Woodward: Contact stresses for multiply connected regions-the case of pitted spheres.

26) A. Ju. IšlinskiJ : Consideration of the theory of cracks from the point of view of contact problems of the theory of elasticity. 